\title{
Dynamics of relationships in a family seen from perception about fathering
}

\author{
(A Case Study on the Families in Makassar)
}

\author{
Syuraswati Muhiddin \\ Department of Psychology \\ Hasanuddin University \\ Makassar, Indonesia \\ syuramuhiddin@gmail.com
}

\author{
Arlina Gunarya \\ Department of Psychology \\ Hasanuddin University \\ Makassar, Indonesia
}

\author{
Dyah Kusmarini \\ Department of Psychology \\ Hasanuddin University \\ Makassar, Indonesia
}

\begin{abstract}
- this study aims to understand the dynamics of relation within family in terms of family member's perception about fathering. Fathering refers to the role of father, including role expectation and role performance. This research is a qualitative descriptive study using systemic approach. A total of 10 families were selected based on family functioning as measured with the Family Assessment Device (FAD), which is filled by teenagers of the family. Ten families were divided into two groups based on the general functioning scores of FAD, that is high-family functioning and low- family functioning. Father, mother and two children minimal of the family were interviewed using open-questionnaire about fathering. The results show that fathers perceive their role mainly related to the role of assistance, including the mentoring of character development and cultivation of religious values, then the instrumental role and the affective role. Mother perceives that fathers should perform their role of instrumental and affective. Meanwhile, the fathers showed less of performance in affective relationships. Children also tend to perceive his father's lesser role in fostering an affective relationship and communicate their development. Interaction within the family is more determined by appreciation and the meaning of the interaction than the ways of interaction are realized. Future research needs to involve the researcher as semiparticipant to obtain deeper insight about family relation.
\end{abstract}

Keywords — dynamic of relation; family system; fathering

\section{INTRODUCTION}

Family as a basic unit of society is viewed as a system. Family is an open system compiled of components (father, mother, children, etc.) which is able to form subsystem [1]. The components to be related each other and to be connected with the other systems (other family, school, and work place). In the same way, the subsystem and the components within is a part of bigger and broader system called supra system (community and society). Because of the characteristic, interaction of every component within system is needed to maintain the system's effectiveness and organization. The condition is indicated by the quality of family member relation through communication. The more intense their communication, the better and stronger their relationship [2][3][4]. Nevertheless, data showed that divorce level increases, including in Indonesia. Indonesia is the one of countries with high divorce level in Asia Pacific.
Around $70 \%$ of the divorce cases are caused by disharmony pushing wife to claim their husband [5]. The data may indicate that the relation within system is not optimal.

Basically, the function of family is to fulfill biological, psychological and social needs of its members and to provide supporting circumstance for its member's development [4]. The basic function can be actualized such us by parenting. Parenting is continual interaction, collaboration and clear rule and consensus among parents, children and society [3]. The quality of parenting reflects the quality of relation between father and mother, retaining a whole family system to remain effective. Some facts show that only mother did involve in parenting. Besides, people is still agreed that parenting is main duty of mother (About 50\% - 60\% parents), while main responsibility of father is work and good provider (about $60 \%$ parents) [6][7][8][9]. The data could reflect the lack of optimal collaboration which finally could result unorganized family system.

\section{- Family Functioning and Fathering}

Discussion about the function of family will encounter with family functioning. But the two terms are different. Family functioning focused on how capable a family to attain its function [4]. Family functioning refers to the roles played by every family member as well as attitude and behavior showed by each member within family [10]. Father is the one of family members that has certain roles and duties, including parenting. Therefore, fathering is important to increase family functioning. Nonetheless, some fathers are present physically but he is not available psychologically. Thirty eight university students who were asked about their relation with their parent said that they were close to their mother than their father because their mother has much more time than father do. Discussion Result of International Course of Indigenous Psychology Hasanuddin University, explained that mother is more open-minded, helpful, and heartening, whereas father is busy, cavalier and judge-mental. The facts support that father's role was less perceived, especially by children. 


\section{- Role-related Terms}

Role is about some other terms, expectation, evaluation and performance [11]. Fathering expectation is owned by other family members. Fathering performance is carried out by father. Evaluation is given by father as actor and the other family members [11]. The congruence between role expectation and role performance that could be known by evaluation may indicate that interaction between father and the other component (mother and children) is existed. Hence, the family functioning is good. There was a research finding that perception about good father according to father and children was different. Father emphasized on role related to good model, listener and teacher for his children. Meanwhile children want their father to give an independency and to release his control for children [12]. The final objectives of this research are to understand the dynamic of family relation through examining the father's role according to father, mother and children in both family with high functioning and family with low functioning.

\section{METHOD}

This research is basically a case study on ten families in Makassar. Subject selection of this research consists of two stages. The systemic approach is used due to understanding that family is a system. Therefore, research participant is not only one component but also more than one component.

\section{A. Family Functioning}

First stage involved 231 students from 8 senior high schools. The schools were chosen based on their location from CBD (Central Business District) in Makassar. Two schools were selected randomly from CBD I, CBD III, and Non CBD. The students were assessed to determine family functioning scores by using McMaster Family Assessment Device (FAD). There are six dimensions of Family functioning according to McMaster Family Functioning Theory, namely problem solving, communication, role, behavior control, affective involvement and affective responsiveness. The scores were splits into two groups, i.e. high/effective family functioning group (A) and low/ineffective family functioning group (B).

\section{B. Fathering}

Second stage involved ten families of the teenager from the first stage which were chosen by simple random sampling. Five families are from group A (scores $>=$ cut off point 5,5) and five families are from group B (scores < cut off point 5). The other criterion of second selection was the total of children. Family with only one child was not selected. The teenagers also lived together with their parent. The two criteria was grounded by systemic view. The cultural background based on ethnicity perceived by the teenagers was also considered. Only Bugis-Makassar or Mixed Ethnic (Bugis-Makassar with other ethnicity) was included.

In this research, fathering was known from evaluation of father, mother, and children on father's role performance, father's role perception according to father, and father's role expectation according to mother and children. Father, mother and two to three children were interviewed by using open- questionnaire constructed by researcher based on some aspects of fathering according to Finley and Schwartz [13] and Hawkins et al. [14]. The aspect also pointed to three aspects of father involvement according to three dimensions of father involvement, engagement, accessibility, and responsibility [15][16].

\section{RESULT AND DISCUSSION}

The result of this research is presented in two parts based on data collected.

\section{A. Role Expectation and Role Perception on Fathering}

Two tables below show the data about what father perceived about their role and what mother and children expect related to father's role. In general, there are no differences among three members in term of role expectation and perception. Basically, what father perceived about his role is equivalent with what mother and children expect. But, the difference could be seen in the priority of the role.

TABLE I. FAMILY WITH HIGH FAMILY FUNCTIONING

\begin{tabular}{|c|c|c|c|}
\hline \multirow{2}{*}{$\begin{array}{l}\text { Rank of } \\
\text { Priority }\end{array}$} & \multicolumn{3}{|c|}{ Role Expectation and Role Perception } \\
\hline & Father & Mother & Children \\
\hline 1 & $\begin{array}{l}\text { Providing family } \\
\text { basic needs. } \\
\text { Teaching } \\
\text { religion } \\
\text { Leader and role } \\
\text { model. } \\
\text { Fighter }\end{array}$ & $\begin{array}{l}\text { Providing livelihood } \\
\text { Protecting family } \\
\text { Good role model }\end{array}$ & $\begin{array}{l}\text { Providing material } \\
\text { Leader and family } \\
\text { head } \\
\text { Instilling religious } \\
\text { values } \\
\text { Become friend } \\
\text { Giving affection } \\
\text { Respected }\end{array}$ \\
\hline 2 & $\begin{array}{l}\text { Good role model } \\
\text { Supporting } \\
\text { education } \\
\text { Advising } \\
\text { Educator } \\
\text { (Teacher) }\end{array}$ & $\begin{array}{l}\text { Instilling religious } \\
\text { values } \\
\text { Giving material } \\
\text { Instilling discipline } \\
\text { Giving attention and } \\
\text { love } \\
\text { Become close friend } \\
\text { for wife and children }\end{array}$ & $\begin{array}{l}\text { Protecting family } \\
\text { Educating and } \\
\text { teaching } \\
\text { Education assistance } \\
\text { Giving affection } \\
\text { Become friend } \\
\text { Advising }\end{array}$ \\
\hline 3 & $\begin{array}{l}\text { Teaching ethic } \\
\text { Spiritual } \\
\text { assistance } \\
\text { Guiding } \\
\text { Giving solution }\end{array}$ & $\begin{array}{l}\text { Supporting education } \\
\text { Showing gentleness and } \\
\text { love } \\
\text { Making available time } \\
\text { for family }\end{array}$ & $\begin{array}{l}\text { Guiding } \\
\text { Protecting } \\
\text { Giving material } \\
\text { Making a decision } \\
\text { Brother } \\
\text { teaching } \\
\text { independency } \\
\text { Supporting children } \\
\text { Advising }\end{array}$ \\
\hline
\end{tabular}


TABLE II. FAMILY WITH LOW FAMILY FUNCTIONING

\begin{tabular}{|c|c|c|c|}
\hline \multirow{2}{*}{$\begin{array}{l}\text { Rank of } \\
\text { Priority }\end{array}$} & \multicolumn{3}{|c|}{ Role Expectation and Role Perception } \\
\hline & father & Mother & Children \\
\hline 1 & $\begin{array}{l}\text { Instilling religious } \\
\text { values and } \\
\text { spirituality } \\
\text { Good leader and } \\
\text { model } \\
\text { Close friend } \\
\text { Giving compassion } \\
\text { and love }\end{array}$ & $\begin{array}{l}\text { Providing } \\
\text { livelihood } \\
\text { Taking } \\
\text { responsibility for } \\
\text { family }\end{array}$ & $\begin{array}{l}\text { Providing livelihood } \\
\text { Family Head and } \\
\text { leader } \\
\text { Protecting family } \\
\text { Managing children } \\
\text { Praying for children } \\
\text { Controlling family } \\
\text { Guiding family }\end{array}$ \\
\hline 2 & $\begin{array}{l}\text { Supervising } \\
\text { Educating } \\
\text { Loving children } \\
\text { Supporting school } \\
\text { and education }\end{array}$ & $\begin{array}{l}\text { Protecting family } \\
\text { Be close to } \\
\text { children } \\
\text { Giving affection } \\
\text { Guiding family }\end{array}$ & $\begin{array}{l}\text { Educating and } \\
\text { teaching children } \\
\text { Family Head and } \\
\text { leader } \\
\text { Protecting family } \\
\text { Providing livelihood } \\
\text { Giving attention on } \\
\text { children } \\
\text { development }\end{array}$ \\
\hline 3 & $\begin{array}{l}\text { Supporting talent } \\
\text { development } \\
\text { Advising } \\
\text { Leader, Family } \\
\text { Head } \\
\text { Educating children } \\
\text { Supporting } \\
\text { extracurricular } \\
\text { activities } \\
\text { Monitoring } \\
\text { children's social life }\end{array}$ & $\begin{array}{l}\text { Supervising } \\
\text { Providing } \\
\text { facilities } \\
\text { Advising } \\
\text { Teaching } \\
\text { responsibility }\end{array}$ & $\begin{array}{l}\text { Advising } \\
\text { Guiding children } \\
\text { Providing material } \\
\text { Good role model } \\
\text { Showing affection } \\
\text { Managing children }\end{array}$ \\
\hline
\end{tabular}

Family members from two groups also had same expectation about what man should do as father of a family. Even though, various kinds of role were found in high family functioning. Particularly, it could be found that father's perception about his role was mostly emphasized on mentoring, educating, instilling and assisting roles. Affective role was less perceived by father. Mother's expectation regarding father was mainly pertinent to instrumental and affective roles. Children's expectation toward their father also concerned to instrumental and affective role.

\section{B. Role Evaluation Towards Fathering Performance}

Attempting to realize their role, father of group A-family and father of group B-family showed similar ways. These were identified through evaluation of father, mother and children. On the affective relationship aspect, the fathers usually gathered with children, talked or played together, including played sport. Father instilled religious values, encouraged children to pray and worship, and taught ethics and manners. In developing career, father supported their children's career development, talents and skills, such as, through providing facilities and school requirements. More various ways performed by father supporting character development of children. Father monitored children activities, gave advices and suggestions, reminded children, educated discipline, and showed an authority related to establishing obedience. On the instrumental role aspects, father maintained and guarded his family, provided livelihood, granted children needs, and guided to the good way. Father also accomplished domestic roles to help mother. Father used to clean up house.

Compared with evaluation towards the ways of father's role actualization which was more synchronous, quality of the actualization was much more incongruent according to evaluation of father, mother and children. In general, the way of father to perform fathering was not much more different in both group A-family and group B-family. The difference could be seen on the meaning, understanding, appreciation and internalization of the fathering performance. It could be understood that there was usual pattern of evaluation toward fathering. Father valued his self with high point of performance but mother and children conferred a lower point, and vice versa. Mother and children appraised father role performance with high point whereas father perceived their self in less fathering. The result also showed that father was regarded less performance in creating affective relationship. Mostly father played instrumental and teaching roles.

Furthermore, there is an underlined result of this research. There were some family members from low family functioning group perceived that their father was much involved in fathering. Even he was more involved than did father of high family functioning group. Despite the good evaluation, the consistency of evaluation was questionable. The congruence of evaluation among father, mother and children was more consistent in family with high family functioning score.

\section{Some Insight}

There are some findings that could be discussed and researched further. In spite of social and economic change followed by the change of perspective on fatherhood [15], the traditional view was remain exist. Father is a Family Head and associated with instrumental role, leadership, aggressiveness, interpersonal violence and emotional toughness [17]. It is why father is not familiar with affectionate relation. Social norms constructed in long time period have reinforced father to perform common role in a society. Moreover, it can be inferred from the explanation that based on three father involvement dimensions [15][16], father is more involved in responsibility dimension than accessibility and engagement dimensions.

Role expectation and role perception could reflect attitude, values and belief in a culture. The psychological aspects could ground certain explanations about the roles played by man in family. This social context of this research is Bugis and Makassar culture. This implies that Bugis-Makassar people believe that appropriate father commits as leader, financial provider, and family protector, who is deal with teaching and educating as well as discipline and instilling religious and moral values. The belief supports the prior finding [18]. Father also should reflect authority, strength and firmness.

As noted previously, what mother and children expect on father role and what father perceives on his role were not different in both family with high family functioning and family with low family functioning. The difference was more recognized by evaluating the meaning of interaction through role actualization. In connection with family functioning, role 
expectation is not associated with family functioning. Family functioning is associated with role performance because interaction is existed in the performance. Furthermore, the meaning of interaction depends on perception and our subjective evaluation. The role discrepancy, when the role expectation is not congruence with role performance [19], is also related to family functioning because it implies that communication between father and the other family members is insufficient. In the beginning of introduction, we are escorted that family is system. Therefore, family functioning is not determined only by one family member, e.g. father. All of family members need to contribute in developing good interaction to produce system energy.

As a social system, family is interrelated organization. It means that a change of one member can influence the other members and a whole family system. The fathers who is aging, retiring, getting a new job, and having an accident, differs in trying to do fatherhood which affects family functioning.

Definitely, family is dynamic structure and function, moving through time. Family has stages like human development called family life cycle [1]. The stages is started with single young adults leaving their home, joining of families through marriage, accepting young children in family as new members, raising adolescent, launching children, and experiencing family in later life. Every stage needs different main roles that should be performed by family members, especially father and mother. Every stage has different kind of main problems and solutions that give different learning and understanding. Family functioning might be also associated with family life cycle.

\section{LIMITATION AND FUTURE WORK}

This research focused on the subjective perception and evaluation to examine interaction among family members. Since it is a subjective aspect, it can be not assured that the quality of interaction is real. There is another choice of qualitative method to understand the real interaction. That is to become a semi-participant observer. Researcher can stay in a family home for a while to gain better explanation and deeper insight.

This work represents comprehensive effort to understand family as a social system. Fathering, the main topic discussed, is viewed as a part of social system, i.e. family system. Involving family system components (i.e. father, mother and children), supported the validation of data in this qualitative. Although we try to infer some general conclusion and present some insights, we must not generalize the data and the conclusion due to the characteristic of qualitative research. We plan to do the other research with quantitative method to test this research finding. Fathering scale will be constructed based on this work results.

\section{ACKNOWLEDGMENT}

We thank Rizky Amalia Jamil for assistance with data collecting and particular techniques. We would also like to thank Great Research Team for assistance in collecting and compiling data. We are also immensely grateful to an "anonymous" reviewer for her so-called insights and for her comments that greatly improved the earlier manuscript

\section{REFERENCES}

[1] R.R. Greene. Human Behavior Theory and Social Work Practice. New Brunswick, USA: Transaction Publisher, 2008.

[2] I. Carter. Human Behavior in the Social Environment, $6^{\text {th }}$ ed. New Brunswick, USA: Aldine Transaction, 2011.

[3] J. Brooks, The Process of Parenting. Yogyakarta: Pustaka Pelajar, 2011.

[4] J.J. Schwab, H.M.Gray-Ice, and F.R. Prentice. Family Functioning: The General Living Systems Research Model. New York: Kluwer Academic Publishers, 2002.

[5] BKKBN. "Angka Perceraian di Indonesia Tertinggi di Asia-Pasifik," Internet:www.bkkbn.go.id/, Dec 2013 [July. 26, 2017]

[6] D. Briawan and T. Herawati. (2008, Jan.). "Peran Stimulasi Orang tua terhadap Perkembangan Anak Balita Keluarga Miskin," Jurnal Ilmu Keluarga dan Konsumen. [Online]. 1(1), pp.63-76. Available: http://ikk.fema.ipb.ac.id/v2/images/jikk/v1n1_6.pdf [July.26,2017]

[7] F. Hidayati, Kaloeti, V.S. Dian and Karyono. "Peran Ayah dalam Pengasuhan Anak (Fathering in parenting)," Jurnal Psikologi Undip, Vol. 9, pp. $1-10,2011$

[8] H. Elia, "Peran Ayah dalam Mendidik Anak (Role of Father in Educating Children)," Veritas: Theology and Service Juornal, vol. 1, pp. 105-113, April. 2000.

[9] Pikiran Rakyat Online. "Persepsi Masyarakat, Pengasuhan Anak Kesampingkan Peran Ayah". Internet: www.pikiranrakyat.com/bandung-raya/, April. 19,2012 [Aug. 1, 2017].

[10] A. Cendra. "Relationship between Family Functioning and Loneliness on Indonesian Adolescents," Bachelor Thesis, Faculty of Psychology, Indonesia University, 2012.

[11] E.M. Shaw and P.R. Costanzo. Theories of Social Psychology, $2^{\text {nd }} e d$. Japan : McGraw Hill, 1982.

[12] M.T. Morman and K. Floyd. "Good Fathering: Father and Son Perceptions of What It Means to Be a Good Father", Fathering, vol. 4, pp. 113-136, 2006.

[13] G. Finley and S.J. Schwartz. "The father involvement and nurturant fathering scales: retrospective measures for adolescent and adult children," Educational and Psychological Measurement, vol. 64, pp. 143-64, Feb. 2004.

[14] A.J. Hawkins et al. "The Inventory of Father Involvement: A Pilot Study of a New Measure of Father Involvement," The Journal of Men's Studies, vol.10, pp. 183 - 196, 2002.

[15] N.J. Cabrera, C.S. Tamis-LeMonda, R.H.Bradley, S. Hofferth and M.E. Lamb, "Fatherhood in the Twenty-First Century," Child Development, vol. 71, pp. 127-136, 2000.

[16] Kimmel and M.A. Messner. Men's Live. United States: Macmillan Publishing Company, a division of Macmillan, Inc., 1992, pp. 521-535.

[17] G.R. Brooks and L.A. Gilbert. Men in Families: Old Constraints, New Possibilities. In Levant, F. Ronald and W.S. Pollack (Eds.1), A New Psychology of Men. United States: BasicBooks, A Division of Harper Collins Publisher, Inc, 1995, pp. $252-279$.

[18] H. Hauari and K. Hollingworth. (2009). "Understanding fathering. Masculinity, Diversity and Change,". [Online]. Available: www.jrf.org.uk/sites/files/jrf/understanding-fathering-diversity-full.pdf, [July.31, 2017]

[19] P. Kumar, P. Kaur and K. Kalra. "Role Expectations, Role Perceptions and Role Performance of Extension Personnel," American International Journal of Research in Humanities, Arts and Social Sciences, vol.4, pp. 6-13, 2013.

[20] B. Carter and M. McGoldrick. The Expanded Family Life Cycle. Individual, Family, and Social Perspectives, $3^{\text {rd }}$ ed. USA: Pearson Education Company, 2004. 